\title{
ID7 Isolated from Bauhinia variegata Stem Inhibits Tumor Progression and Metastatic Mechanisms of Triple Negative Breast Cancer in Vivo
}

\section{ID7 fracttion from Bauhinia variegata Inhibits Triple Negative Breast Cancer}

Kamilla Monteiro dos Santos ${ }^{1,2}$, Izabela Natalia Faria Gomes ${ }^{3}$, Renato José Silva Oliveira ${ }^{3}$, Fernanda E. Pinto ${ }^{4}$, Bruno Oliveira ${ }^{4}$, Fabrício P. Batista ${ }^{5}$, Rafael Cesar Russo Chagas ${ }^{1}$, Hélio B. Santos ${ }^{6}$, Ralph G. Thomé ${ }^{\text {, }}$ Wanderson Romão ${ }^{4}$, Rui Manuel Reis ${ }^{3,7,8}$, Maria Luiza Vilela Oliva ${ }^{5}$ and Rosy Iara Maciel de Azambuja Ribeiro ${ }^{1}$ 1. Laboratory of Experimental Pathology, Federal University of São João del-Rei (UFSJ), Divinópolis, MG, Brazil

2. José do Rosário Vellano University, Unifenas, Divinópolis, MG, Brazil

3. Molecular Oncology Research Center (CPOM), Barretos Cancer Hospital, Barretos, SP, Brazil

4. Petroleomic and Forensic Chemistry Laboratory, Department of Chemistry, Federal Institute of Espírito Santo (IFES), Vitória, ES, Brazil

5. Chemistry Department, Federal University of São Paulo, Brazil

6. Tissue Processing Laboratory, Federal University of São João del-Rei (UFSJ), Divinópolis, MG, Brazil

7. Life and Health Sciences Research Institute (ICVS), Medical School, University of Minho, Braga, Portugal

8. 3ICVS/3B's-PT Government Associate Laboratory, Guimarães, Braga, Portugal

\begin{abstract}
Background: The breast cancer has been the most common form of cancer among women. The triple negative subtype represents $20 \%$ of all breast cancer cases in the world and is standing out by affecting young women and being aggressive. The main cause of death of patients with cancer is due to metastasis, which can reach the liver and lungs. Objective: The activities of ID7 fraction of the stems of Bauhinia variegata L. on breast cancer, lung metastasis and liver inflammatory process were evaluated. Method: ID7 was characterized by mass-spectrometry. The viability of murine mammary cells (4T1) treated with ID7 was assessed by MTT, trypan blue and fluorescence assay and viability of BT-20, MDA-MB-231 and MCF-7 human breast cancer tumor lines by MTS. The cell migration, invasion using matrigel and adhesion were performed. The expression of cell death proteins was quanitified by western blot and the gelatinases by zimogram. The ID7 activity of the tumor (4T1) and metastatic progession in vivo was evaluated. Results: ID7 reduced the 4T1 and MDA-MB-231viability and increased the late apoptosis, inhibited the 4T1 migration and invasion, increased the 4T1 adhesion and decreased the secreted active gelatinases. ID7 also increased the expression of PARP, caspase-7 and caspase-8, RIP and TNF-R1. In vivo, the ID7 decreased the volume and weight of the tumors and decreased lung metastasis and inflammation in the liver. The characterization showed mainly the presence of oleic acid, myricetin, quercetin and kaempferol in ID7. Conclusion: Thus, it was found that ID7 fraction exhibits selective antitumor and on the mechanisms of breast cancer metastasis activity, preventing lung metastasis and inflammation in the liver. It is suggested that fatty acids and flavonoids are correlated with such activities.
\end{abstract}

Key words: 4T1 cells, MDA-MB-231, medicinal plants, kaempferol, gelatinases, apoptosis, cell viabilty, in vivo.

\section{Introduction}

Corresponding author: Rosy Iara Maciel Azambuja Ribeiro, $\mathrm{PhD}$ in Pathology, research field: laboratory of experimental pathology.
The absence of estrogen, progesterone and human epidermal growth factor receptors define the triple negative breast cancer. Also, it is associated with an early recurrence of the disease and an unfavorable outcome due to the difficulty of treatment. In addition, 
clinical experience suggests that women with metastasis incidence of triple negative breast cancer present recurrence even when submitted to various types of therapies [1]. During metastasis, tumor cells need to overcome physiological barriers by modifying adhesion properties, promoting local and blood or lymphatic system invasion. Tissue remodeling of invasive breast cancer is related to the enzymes overexpression, especially, of the matrix metalloproteinases (MMPs) [2, 3]. Subsequently, the tumor cells colonize a new place through the remodeling of the tumor microenvironment [4].

Currently, there is evidence that the antitumor activities of medicinal plants are mainly due to oxidative stress modulation and/or reprogramming of the extracellular environment in several types of cancer. In addition, herbal medicines can induce cell death by apoptosis, acting on initiation and tumor resistance [5]. In this context, species of the Bauhinia genus have shown activities on tumor progression stages [6-8]. Bauhinia variegata $\mathrm{L}$. is a species of Asian origin, disseminated in the Brazilian territory, along with natural vegetation and in urban areas [9]. Studies of our research group with a variety of this species have shown antitumor and antimetastatic activities of its extracts due to the death induction of human cervical carcinoma (HeLa) cells by Caspase-3, RIP and TNFR-1 activation, besides inhibition of cells migration and invasion [8].

In this way, this study investigated the action of a fraction obtained from Bauhinia variegata stems (ID7), in the tumor development in a murine (4T1) breast cancer model, both in vitro and in vivo, as well as its action in a human breast cancer cell line. The elucidation of the substances present in this extract may have implications in new antitumor and antimetastatic drug development.

\section{Methodology}

\subsection{The Plant}

Bauhinia variegata L. samples were collected in the urban area of Divinópolis, Brazil (209'2.301" S, 44 53'18.879" W, $703 \mathrm{~m}$ ), identified and deposited in the Herbarium of the Federal University of Minas Gerais (UFMG) under identification code BHCB161589.

\subsection{Extract Achievement}

The dried and cleaned stems were triturate and the extracts were produced by using ethanol $(70 \% \mathrm{v} / \mathrm{v})$ for exhaustive maceration and subsquent lyophilization. The crude extract was partitioned using solvents of increasing polarities $(1: 1 \mathrm{v} / \mathrm{v})$ : hexane, chloroform, ethyl acetate and ethanol (70\%). Gravity chromatography was carried out with the silica Gel 60 as stationary phase to obtain the fractions. The column elution was also performed with increasing polarity $(1: 1 \mathrm{v} / \mathrm{v})$ solvent: hexane, chloroform, ethyl acetate and methanol. The resulting solution was freeze-dried and stored at $-20{ }^{\circ} \mathrm{C}$ until use. The column fraction denominated ID7 was selected for this study because on the one hand it presented high mass yield and on the other hand it reduced the viability of other tumor cell lines in previous studies (unpublished).

\subsection{Characterization by Mass Spectrometry (ESI-MS) and UHPLC-ESI-QToF}

To identify the compounds present in ID7, $10 \mu \mathrm{L}$ of this fraction was dissolved in $1,000 \mu \mathrm{L}$ of acetonitrile, which was directly infused $(4.0 \mathrm{~L} / \mathrm{min})$ in an ESI (-) injector. A mass spectrometer (model 9.4 T Solarix, BrukerDaltonics, Bremen, Germany), negative ion mode, ESI (-) was used over a mass range $(\mathrm{m} / \mathrm{z})$ of 150-1,500 with a nebulizer gas pressure of $1.5 \mathrm{bar}$, capillary voltage of $3.9 \mathrm{kV}$ and capillary transfer temperature of $200{ }^{\circ} \mathrm{C}$. All mass spectra were externally calibrated using NaTFA (m/z 200 to 1,200) and mass accuracy was $<5 \mathrm{ppm}$. The spectra were acquired and processed using Data Analysis software.

To complement the analysis UHPLC-ESI-QToF was also performed. The Ultra Performance Liquid Chromatography was performed using UHPLC System 
BEH C18, $\left(1.7 \mu \mathrm{m}, 2.1 \times 100 \mathrm{~mm}, 30{ }^{\circ} \mathrm{C}\right)$ column and eluents: $0.1 \%$ formic acid in water (A); $0.1 \%$ formic acid in acetonitrile (B) with flowrate at $0.4 \mathrm{~mL} / \mathrm{min}$ and gradient with linear changes (min/\% B): 0/1, 0.75/1, 6.0/99, 8/99, 9/1, 1 and injection volumn: $1 \mu \mathrm{L}$. The data were analyzed using ESI-QToF analysis, negative ESI spectrometry.

\subsection{Tumor Cells and Culture Conditions}

Murine mammary adenocarcinoma cells (4T1) were maintained in RPMI-1640 culture medium, supplemented with fetal bovine serum (FBS) $10 \%$ and streptomycin/penicillin (s/p) 1\% (v/v). BT-20 (Her2 positive), MCF-7 (positive hormone and Her2 negative) and MDA-MB-231 (triple negative) breast cancer cells were maintained in DMEM culture medium supplemented with $10 \%(\mathrm{v} / \mathrm{v})$ SFB and $1 \%(\mathrm{v} / \mathrm{v}) \mathrm{s} / \mathrm{p}$. All cells were maintained in an oven at $37{ }^{\circ} \mathrm{C}$ in a humidified atmosphere enriched with $5 \%(\mathrm{v} / \mathrm{v}) \mathrm{CO}_{2}$.

\subsubsection{Murine splenocytes (MS)}

After the euthanasia of two Balb/c mice, the spleens were removed aseptically. The tissues were placed in a sterile tube with saline solution $(\mathrm{NaCl} 9 \%)$ and kept refrigerated. After that, the spleens were chopped and the cell suspensions were centrifuged (2,000 rpm/5 min at $4{ }^{\circ} \mathrm{C}$ ). The supernatant was discarded and the pellet was resuspended in $1 \mathrm{~mL}$ of DMEM culture medium (10\% FBS and $1 \% \mathrm{~s} / \mathrm{p})$. The cell count was measured with a hemocytometer using the trypan blue dye exclusion method.

\subsection{Viability Assays of Murine Cell Lines}

The cells were plated in 96-well plates for $24 \mathrm{~h}$. Then, the cells were treated with ID7 at 5, 10, 25, 50, 75 and $100 \mu \mathrm{g} / \mathrm{mL}$ for 24,48 and $72 \mathrm{~h}$. After the treatment time, the medium containing ID7 was removed and $100 \mu \mathrm{L}$ of the MTT (3-(4,5-Dimethylthiazol-2-yl) -2,5-Diphenyltetrazolium Bromide) was added into each well and the cells were incubated for $3 \mathrm{~h}$. Then, $100 \mu \mathrm{L}$ of DMSO was added for solubilization of the formazan crystals and absorbance read at $570 \mathrm{~nm}$. The
$\mathrm{IC}_{50}$ values obtained in $72 \mathrm{~h}$ of treatment were used in the other 4T1 assays. For the cell viability assay using trypan Blue $2 \times 10^{4}$ cells/well of the $4 \mathrm{~T} 1$ strain were added in 96 well plates. The treatment also consisted of ID7 at the same concentrations of MTT assay. After the treatment time, cells from each well were trypsinized, stained with $0.04 \%$ trypan blue $(\mathrm{m} / \mathrm{v}$ in water) and viable cells were counted using hemocytometer.

\subsection{Selectivity Index (SI)}

To determine the selectivity index (SI), the ratios between the cytotoxic concentrations of ID7 for the splenocytes and the $\mathrm{IC}_{50}$ values reached for the $4 \mathrm{~T} 1$ lineage in $72 \mathrm{~h}$ of treatment. It was considered selective treatment with SI equal to or greater than 1.0 [10].

\subsection{Propidium Iodide/Acridine Orange Dual Staining}

The $4 \mathrm{~T} 1$ cells were seeded $\left(2 \times 10^{4}\right.$ cells/well $)$ and after $24 \mathrm{~h}$, they were treated with ID7 $(25 \mu \mathrm{g} / \mathrm{mL})$ and Cisplatin (30 $\mu \mathrm{g} / \mathrm{mL})$ as the positive control. After $72 \mathrm{~h}$ of treatment, the cells were trypsinized, centrifuged (2,000 rpm/5 min) and stained with Propidium Iodide (10 $\mu \mathrm{g} / \mathrm{mL}$ PI) and $10 \mu \mathrm{L}$ of Acridine Orange (AO 10 $\mu \mathrm{g} / \mathrm{mL}$ ). Cell morphology was evaluated using fluorescence microscopy (FITC). Twenty photographs (200× magnification) of random fields were taken and the cells present in them were counted.

\subsection{Human Cell Viability Assay}

The action of the ID7 fraction was also evaluated on the human breast cancer cell lines MCF-7, MDA-MB-231 and BT20 from MTS assay. For this test, MCF-7, MDA-MB-231 and BT20 cells were plated $\left(5 \times 10^{3}\right.$ cells/well) separately and incubated for $24 \mathrm{~h}$. Then they were treated for $24 \mathrm{~h}$ with $0,5,10,25$, 75, 100, 200 and $300 \mu \mathrm{g} / \mathrm{mL}$ of ID7. After this period the culture medium was removed and the cell viability was quantified using the CellTiter 96 Aqueous Cell Proliferation Assay kit (MTS) (Promega, Madison, $\mathrm{WI}$ ), with $4 \mathrm{~h}$ of incubation and subsequent reading in spectrophotometry at $490 \mathrm{~nm}$. 
2.9 Analysis of Cellular Death Pathway Proteins by Western Blot

BT-20 (Her2 positive), MCF-7 (positive hormone and Her2 negative) and MDA-MB-231 (triple negative) breast cancer cells were maintained in DMEM culture medium supplemented with $10 \%(\mathrm{v} / \mathrm{v})$ SFB and $1 \%$ $\mathrm{w} / \mathrm{w}$. The concentration used was based on the $\mathrm{IC}_{50}$. Then, the cells were lysed using a lysis buffer $[50 \mathrm{mM}$ Tris (pH 7.5), $150 \mathrm{mM} \mathrm{NaCl}$ and 1.0\% NP-40] containing a cocktail of protease inhibitors containing $10 \mu \mathrm{g} / \mathrm{mL}$ Leupeptin and Aprotinin, $1 \mathrm{mM}$ DTT and PMSF and 0.01 M EDTA. Protein concentration was determined, and electrophoresis performed on $20 \%$ SDS-PAGE gel with run-buffer and transferred (Semi-Dry Transfer Unit, TE 70 PWR, GE Healthcare) to nitrocellulose membranes (Amersham Protran, 0.45 $\mu \mathrm{m}$ NC, GE Healthcare). The expression of total and cleaved PARP (\#4967), total and cleaved caspase-8 (\#9746), total and cleaved caspase-7 (\#9492), RIP protein (\#4926) and TNFR-1 (\#3736) were evaluated. All antibodies were diluted and incubated according to the manufacturer's recommendations $(1 / 1,000, \mathrm{v} / \mathrm{v})$. After washing with TBS-T, the membranes were incubated with the peroxidase-conjugated secondary antibody (\#7074, 1:5,000, v/v). The membranes were then developed by chemiluminescence (ECL) and photographed using ImageQuant LAS 4000 mini (GE Healthcare). All the tests were performed in triplicate and normalized with $\beta$-actin.

\subsection{Cell Migration Assay}

Migration of 4T1 cells was measured using the in vitro cell scratch assay. A scratch was made in confluent monolayers of 4T1 cells with a pipette tip followed by extensive washing with serum-free medium to remove cell debris. The ID7 extract (25 $\mu \mathrm{g} / \mathrm{mL}$ ), or $0.1 \%$ bovine serum albumin as vehicle control was then added. Cells were allowed to migrate into the scrapped area for up to 12, 24, 48 and $72 \mathrm{~h}$ at $37{ }^{\circ} \mathrm{C}$. At indicated time points, cells were photographed with the AXIO VERT A1 FL (CARL
ZEISS $\left.^{\circledR}\right)(400 \times)$. The area of migration was calculated with ImageJ software (ImageJ 1.42q/Java1.6.0-10).

\subsection{Invasion Cell Using Boyden Chamber Inserts}

Transwell inserts (5.0 $\mu \mathrm{m}$ pore size) with a polycarbonate filter (Corning BioCoat ${ }^{\circledR}$ ) were used to examine the effects of ID7 $(25 \mu \mathrm{g} / \mathrm{mL})$ on cell migration. 4T1 cells $\left(4 \times 10^{4} /\right.$ well) were suspended in RPMI-1640 and added to the upper chamber. Then, $300 \mu \mathrm{L}$ of media RPMI-1640 (2\% de SFB) was added to the lower chamber following incubation for $24 \mathrm{~h}, 37$ ${ }^{\circ} \mathrm{C}$ and $5 \% \mathrm{CO}_{2}$. After incubation, cells in the upper chamber were carefully removed, and lower chamber cells were fixed with methanol and stained with toluidine blue $(1 \% \mathrm{~m} / \mathrm{v}$ toluidine blue and $1 \%$ de sodium tetraborate $\mathrm{m} / \mathrm{v}$ in PBS). Images were captured under a microscope $(200 \times)$ (CARL-ZEISS $\left.{ }^{\circledR}\right)$ and cells were counted in 5 randomly selected fields of view.

\subsection{Adhesion Cell}

The treatment was made with ID7 $(25 \mu \mathrm{g} / \mathrm{mL})$ for 30 min. Then, adhesion molecules collagen I $(0.08 \mu \mathrm{g} / \mathrm{mL})$, collagen IV $(0.04 \mu \mathrm{g} / \mathrm{mL})$, fibronectin $(0.04 \mu \mathrm{g} / \mathrm{mL})$ and laminin $(0.04 \mu \mathrm{g} / \mathrm{mL})$ were added to the wells and incubation lasted for $3 \mathrm{~h}$. The adherent cells were fixed (5 min) and stained with toluidine blue 1\% (100 $\mu \mathrm{L} /$ well, $5 \mathrm{~min})$. The cells were lysed using SDS (1\%) and the absorbance was measured at $620 \mathrm{~nm}[11]$.

\subsection{Zymogram}

To analyze active gelatinases in the supernatant of the ID7 treated $4 \mathrm{~T} 1$ cells, $5 \times 10^{5}$ of these cells were plated in a 24-well plate until reaching $90 \%$ confluency. The ID7 fraction was applied $(25 \mu \mathrm{g} / \mathrm{mL})$ and remained for $24 \mathrm{~h}$. After this time, the supernatant was collected and refrigerated. Two gels of $7.5 \%$ polyacrylamide and $0.2 \%$ gelatin (TRIS $\mathrm{HCl} 8.8,1.5 \mathrm{M}$ ), copolymerized with sodium dodecyl sulfate (SDS), were made. In each well, $20 \mu \mathrm{g}$ of supernatant proteins was applied of 4T1 cells. Electrophoresis (BioRad Protean II ${ }^{\circledR}$ ) was 
performed under non-reducing conditions $(0.025 \mathrm{M}$ Tris-hydroxymethyl aminomethane (Tris), $0.192 \mathrm{M}$ glycine and $0.1 \%$ SDS (pH 8.5), at $125 \mathrm{~V}$ constants 2.5 $\mathrm{h}$ at $4{ }^{\circ} \mathrm{C}$. After electrophoresis, the gels were washed for one hour under constant shaking in Triton X-100 solution $(2.0 \mathrm{~g} \%, \mathrm{~m} / \mathrm{v})$ to remove SDS. Then, it was submerged in activation buffer $(0.05 \mathrm{M}$ Tris- $\mathrm{HCl}$, $\mathrm{CaCl}_{2} 0.6 \mathrm{~g} \%, \mathrm{~m} / \mathrm{v}, \mathrm{pH}$ 8.0), also under constant shaking for $18 \mathrm{~h}$ at room temperature. After, the gels were stained (Coomassie Blue R-250 0.25\% 45\% methanol and $10 \%$ acetic acid) and discolored for one hour (30\% ethanol, acético10\% acid in distilled water, $\mathrm{v} / \mathrm{v})$. The gels obtained in the electrophoresis were digitized on a flatbed scanner and analyzed by the ImageJ. software. The contrast of the light bands on the dark background of the gel demonstrated the gelatinolytic activity of the gelatinases which was quantified in pixels by the same program.

\subsection{In Vivo Assay}

For induction of tumors in vivo, cultured 4T1 cells were inoculated $\left(4 \times 10^{6}\right.$ diluted in $100 \mu \mathrm{L}$ of RPMI-1640 medium) on the left flank of 16 BALB/C mice, distributed into 2 groups of 8 animals each: control group (100 $\mu \mathrm{L} 0.9 \% \mathrm{NaCl})$ and ID7 group (100 $\mu \mathrm{L}$ ID7, $30 \mathrm{mg} / \mathrm{kg}$ animal weight in $0.9 \% \mathrm{NaCl}$ ). The animals received daily intraperitoneal treatments from the ninth to the 21st day after inoculation of the tumor, were weighed and the tumors were measured with a pachymeter every two days. After 11 days of treatment, the animals were euthanized by cervical dislocation and the tumors, lungs and livers were removed and measured. Nodules macroscopically visualized in the lungs and livers were quantified. Then, organs and tumors were fixed in formalin, processed, and sectioned at 5 micrometers to produce histological slides. The tissues were then stained with Harris Hematoxylin and Alcoholic Eosin (H/E) and analyzed under light microscopy.

\subsection{Statistical Analysis}

Statistical analyses for single comparisons were performed using Student's $t$-test and differences between groups were tested using the ANOVA One Way multiple comparison tests using the GraphPad Prims version 7 program $p<0.05$. All results were submitted to the Shapiro-Wilk normality test with $p>$ 0.05 .

\section{Results}

3.1 The ID7 Fraction from B. variegata Contains Fatty Acids, and Phenols Compound in Their Constitution

We evaluated the profile of secondary compounds identified in ID7 fraction from B. variegata via (ESI-MS) and UHPLC-ESI-QToF analysis (Table 1). Five secondary compounds were identified in their deprotonated form, $\left[\mathrm{M}-\mathrm{H}^{+}\right]^{-}$ions corresponding to compounds: oleic acid, $\left[\mathrm{C}_{18} \mathrm{H}_{34} \mathrm{O}_{2}-\mathrm{H}^{+}\right]$ion of $\mathrm{m} / \mathrm{z}$ 281.24866 (compound 1); Myricetin-rhamnoseor Quercetin-hexose, $\left[\mathrm{C}_{21} \mathrm{H}_{20} \mathrm{O}_{12}-\mathrm{H}^{+}\right]^{-}$ion of $\mathrm{m} / \mathrm{z} 463.0882$

Table 1 Proposed compounds by ESI-MS in ID7 fraction.

\begin{tabular}{|c|c|c|}
\hline $\begin{array}{l}\mathrm{m} / \mathrm{z} \\
\text { theoretical }\end{array}$ & Molecular formula $[\mathrm{M}-\mathrm{H}]^{-}$ & Proposed compound \\
\hline 281.24866 & {$\left[\mathrm{C}_{18} \mathrm{H}_{34} \mathrm{O}_{2}-\mathrm{H}^{+}\right]^{-}$} & $\begin{array}{l}\text { Oleic acid } \\
\text { Myricetin-rhamnose }\end{array}$ \\
\hline 463.0882 & {$\left[\mathrm{C}_{21} \mathrm{H}_{20} \mathrm{O}_{12}-\mathrm{H}^{+}\right]^{-}$} & $\begin{array}{l}\text { or } \\
\text { Quercetin-hexose }\end{array}$ \\
\hline 431.09837 & {$\left[\mathrm{C}_{21} \mathrm{H}_{20} \mathrm{O}_{10}-\mathrm{H}^{+}\right]^{-}$} & $\begin{array}{l}\text { Kaempferol-rhamnoside } \\
\text { Quercetin-rhamnose }\end{array}$ \\
\hline 447.09329 & {$\left[\mathrm{C}_{21} \mathrm{H}_{20} \mathrm{O}_{11}-\mathrm{H}^{+}\right]^{-}$} & $\begin{array}{l}\text { or } \\
\text { Kaempferol-hexose } \\
\text { Quercetin-rutinosid }\end{array}$ \\
\hline 609.146108 & {$\left[\mathrm{C}_{27} \mathrm{O}_{30} \mathrm{O}_{16}-\mathrm{H}^{+}\right]^{-}$} & $\begin{array}{l}\text { or } \\
\text { Kaempferol-di-hexoside }\end{array}$ \\
\hline
\end{tabular}


(compound 2); Kaempferol-rhamnoside, $\left[\mathrm{C}_{21} \mathrm{H}_{20} \mathrm{O}_{10}-\mathrm{H}^{+}\right]^{-}$ion of $\mathrm{m} / \mathrm{z} 431.09837$ (compound 3); Quercetin-rhamnose or Kaempferol-hexose $\left[\mathrm{C}_{21} \mathrm{H}_{20} \mathrm{O}_{11}-\mathrm{H}^{+}\right]^{-}$ion of $\mathrm{m} / \mathrm{z} 447.09329$ (compound 4) and Quercetin-rutinosid or Kaempferol-di-hexoside $\left[\mathrm{C}_{27} \mathrm{O}_{30} \mathrm{O}_{16}-\mathrm{H}^{+}\right]^{-}$ion of $\mathrm{m} / \mathrm{z}$ 609.146108 (compound 5) (Table 1).

\subsection{ID7 Selectively Decreases the Viability of 4T1 Cells}

The 4T1 cells were treated with increasing concentrations of ID7 $(0-100 \mu \mathrm{g} / \mathrm{mL})$ to determine the effect of ID7 fraction on the cell viability. The treatment resulted in $\mathrm{IC}_{50}$ of $29.93 \mu \mathrm{g} / \mathrm{mL}$ and 23.47 $\mu \mathrm{g} / \mathrm{mL}$ at $48 \mathrm{~h}$ and $72 \mathrm{~h}$, respectively (Fig. $1 \mathrm{~A}$ ), with low toxicity on murine splenocytes (> $100 \mu \mathrm{g} / \mathrm{mL}$ ) (Fig. 1C), obtaining a selectivity index of 2.26735905. Trypan blue exclusion assays confirmed the reduction in total cell count with increasing ID7 concentration, IC $_{50}$ $<5 \mu \mathrm{g} / \mathrm{mL}$ (Fig. 1B).

We observed the morphological changes associated with apoptosis were observed in 4T1 cells after ID7 treatment by AO/PI double staining method. The AO and PI double stain were used to analyze the different parameters of cell death [12]. We have observed that the control cells were intact with a round nucleus. On the other hand, the apoptosis characteristics such as blebbing and nuclear chromatin condensation were observed in cells treated with ID7. Besides, the ID7 decreases the viable cells, compared to control ( $p=$ $0.0002)$ and increases cells in late apoptosis ( $p=$ 0.0324). ID7 was not statistically different from treatment with cisplatin (Fig. 2). Each column represents the mean $\pm \mathrm{SD}$ of three independent experiments (ANOVA, One Way).

\subsection{ID7 Is Selective for MDA-MB-231 Human Breast Cancer Lineage}

The cell viability assay with the human breast cancer lineage MDA-MB-231, MCF-7 and BT-20 revealed that ID7 is selective ( IC $_{50} 10.2 \mu \mathrm{g} / \mathrm{mL}$ ) for the MDA-MB-231 lineage, characterized as triple negative
(Fig. 3).

\subsection{ID7 Acts on Extrinsic Cell Death}

The expressions of the pro-apoptotic proteins Caspase 7 (25 $\mu \mathrm{g} / \mathrm{mL})$, TNF-R1 $(15 \mu \mathrm{g} / \mathrm{mL}, 25 \mu \mathrm{g} / \mathrm{mL}$ and $40 \mu \mathrm{g} / \mathrm{mL}$, PARP $(15 \mu \mathrm{g} / \mathrm{mL}, 25 \mu \mathrm{g} / \mathrm{mL}$ and 40 $\mu \mathrm{g} / \mathrm{mL})$ and RIP (15 $\mu \mathrm{g} / \mathrm{mL}$ and $25 \mu \mathrm{g} / \mathrm{mL})$ were positively increased (Figs. 4A-4F) when treated with ID7 for $24 \mathrm{~h}$ at different concentrations. The $\beta$-actin was used in two gels as a control, demonstrating equivalent concentration of protein in all samples.

\subsection{ID7 Fraction Decreases the Migration and Invasion of $4 \mathrm{T1}$ Cells in Vitro}

The healing wound assay evaluates the ability of adherent tumor cells to migrate, seeking confluence in the in vitro environment. Treatment with ID7 decreased the migration of $4 \mathrm{~T} 1$ cells above $60 \%$, at 24,48 and $72 \mathrm{~h}$ of treatment as compared to the control (Figs. 5A and $5 \mathrm{~B})$. The invasion test using the Boyden chamber evaluates the ability of cells to go through the matrigel. Figs. 5C and 5D show the ID7 fraction decreased invasion down to $55 \%$ ( $p=0.0001$ ) (Fig. 5D).

3.6 ID7 Fraction Increased the Adhesion of 4T1 Cells to the Extracellular Matrix Molecules and Decreased the Gelatinases Secretion in $4 \mathrm{T1}$ Cells, in Vitro

The treatment with ID7 was able to increase adhesion of 4T1 cells to collagen I, collagen IV, fibronectin and laminin $(p=0.0001)$. The gelatinases are enzymes secreted by the cells that degrade the components of the extracellular matrix. To examine the effect of ID7 on gelatinase secretion, we treated 4T1 cells with ID7 at $\mathrm{IC}_{50}$ for $24 \mathrm{~h}$ in serum-free media. The zymogram of the supernatant from the 4T1 cells treated with ID7 revealed inhibition of the gelatinases by more than $80 \%$ (Fig. 6B).

3.7 ID7 Fraction Inhibited the 4T1 Tumor and Metastatic Development in Vivo

Tumor volume measurements in alive animals were 


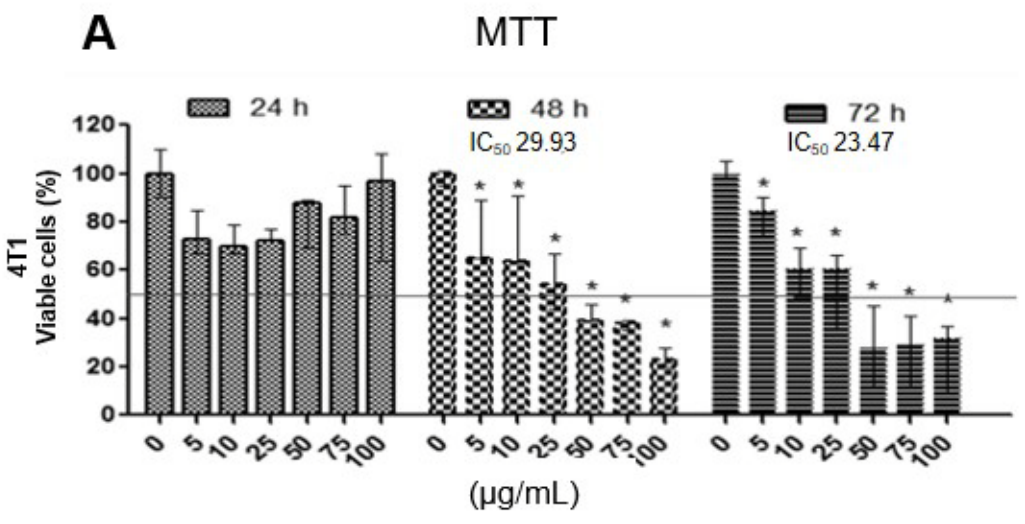

B

Trypan blue
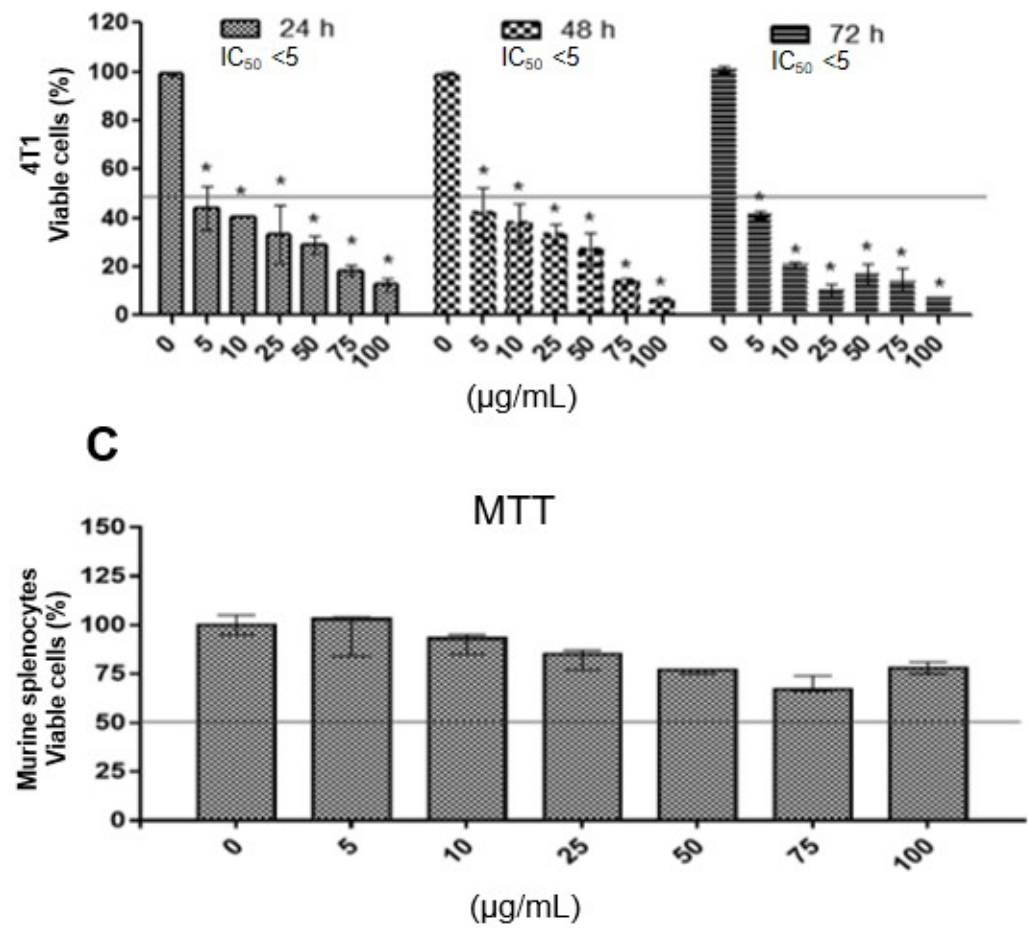

Fig. 1 Viability of 4T1 cell treated with ID7 $(0-100 \mu \mathrm{L})$. A: MTT analysis (48 h and $72 \mathrm{~h}, p=0.0001)$. B: trypan blue exclusion assays ( $24 \mathrm{~h}, p=0.003$; at $48 \mathrm{~h}$ with $p=0.0002$ and, $72 \mathrm{~h}$ with $\mathrm{p}=\mathbf{0 . 0 0 0 1}$ ). C: Murine splenocytes viability treated with ID7 $(0-100 \mu \mathrm{L})$ by MTT assay $(24 \mathrm{~h})$. Values expressed as a mean \pm SEM, 3 separate experiments. Points represent mean \pm SD, $n=$ 3, ANOVA One Way.

performed every two days and showed that ID7 inhibited the 4T1 tumor growth (Fig. 7A). The exposure to ID7 also reduced the animals weight loss, since the control group mice, even with larger tumors, had a lower body weight, compared to the ID7-treated group (Fig. 7B). Tumors histological analyses showed that the control group had a larger area of necrosis than the tumors of ID7 group (Figs. 7F and 7G). It is believed that necrosis evidenced in tumors can be characterized as coagulative necrosis by hypoxia.

The lungs of the group exposed to ID7 presented a lower number of metastasis focus (Figs. 8AI 8AII and $8 D)$ viewed microscopically, which was confirmed by histological analysis that showed reduced tumor area (Figs. 8B and 8E). In addition, exposure to ID7 decreased the infiltrate inflammatory area in the livers 
A
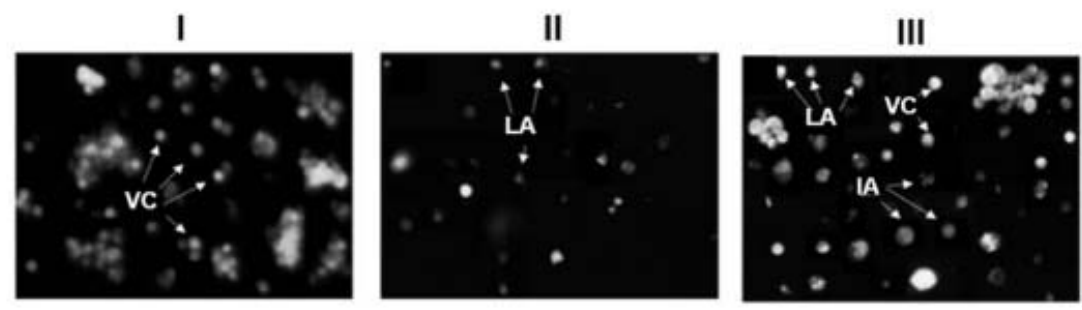

B

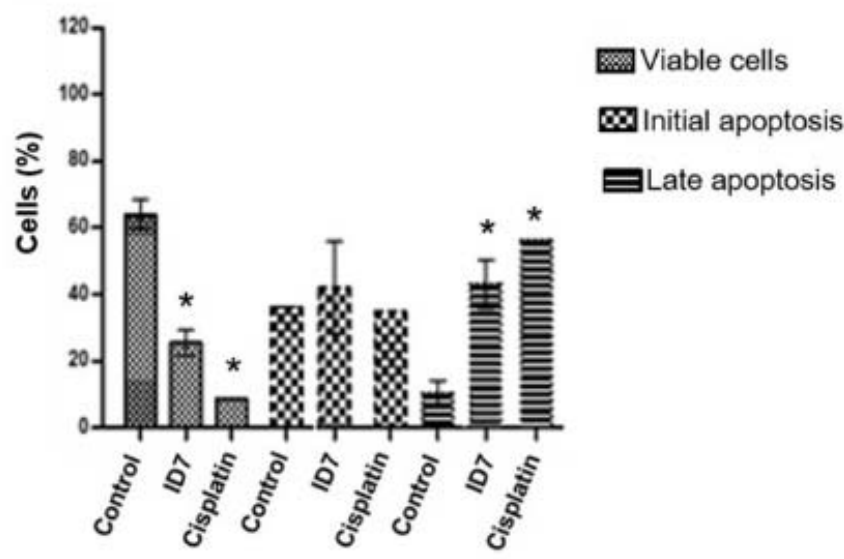

Fig. 2 Viability of 4 T1 cells treated with ID7 $(25 \mu \mathrm{g} / \mathrm{mL})$ and Cisplatin $(30 \mu \mathrm{g} / \mathrm{mL})$. Micrographs of AO and PI double-stained 4T1 cells when treated with DMSO 1\%—control (A-I), Cisplatin $30 \mu \mathrm{g} / \mathrm{mL}$ (A II) and ID7 $25 \mu \mathrm{g} / \mathrm{mL}$ (A III); “VC": viable cells. "IA": initial apoptosis. "LA": late apoptosis. B: Percentage of viable cells in early and late apoptosis (viable cells with $p=$ 0.0002 and late apoptosis with $p=\mathbf{0 . 0 3 2 4}$ ). Each column represents the mean \pm SD of 3 independent experiments (ANOVA One Way).

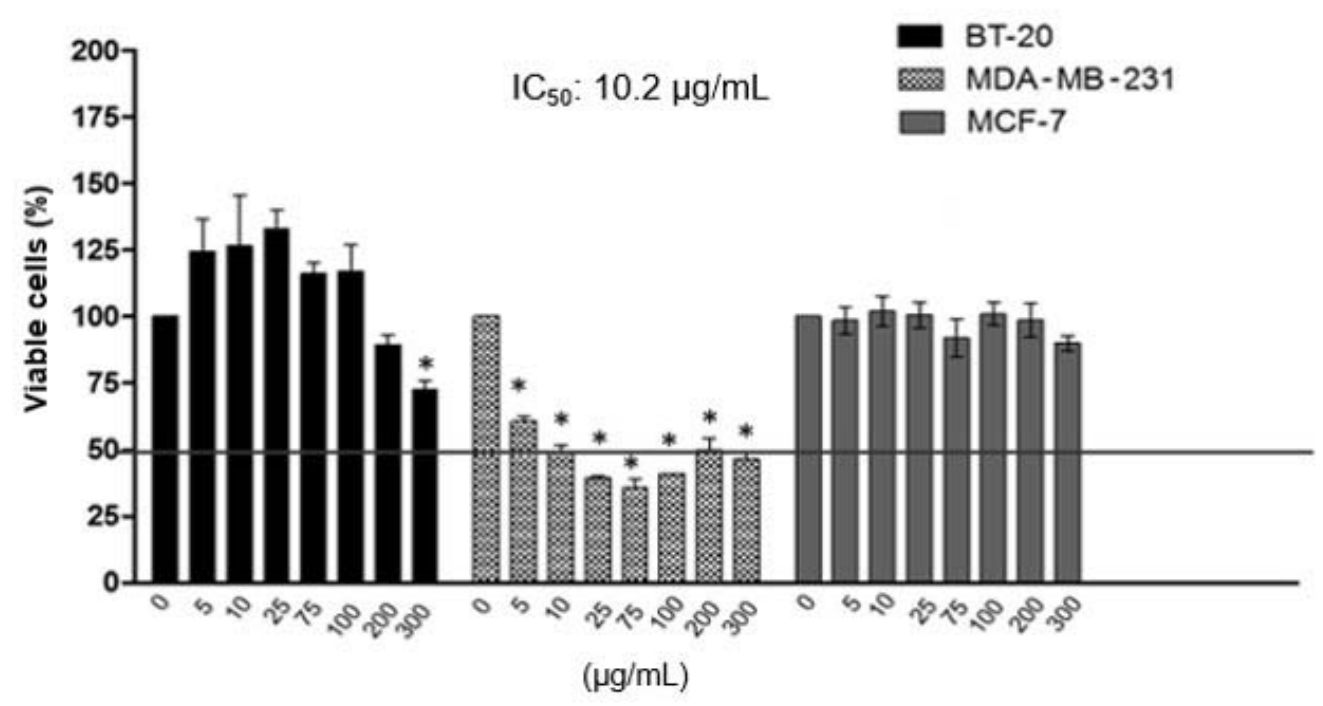

Fig. 3 Viability of human breast cancer cell lines treated with ID7, by MTS assay. Control: 1\% DMSO. BT-20: positive Her2 lineage. MDA-MB-231: triple negative lineage. MCF-7: positive hormone lineage, Her2 negative. Significant difference with $p$ $=0.001$. Each column represents the mean \pm SD of 3 independent experiments (ANOVA, One Way). 
A

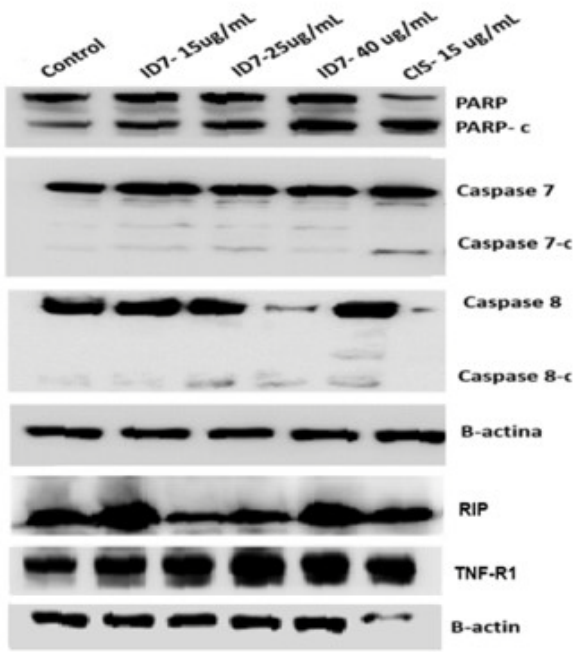

B

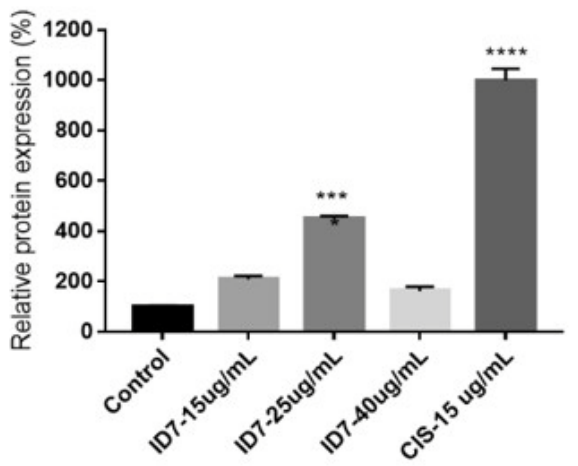

TNF-R1

C

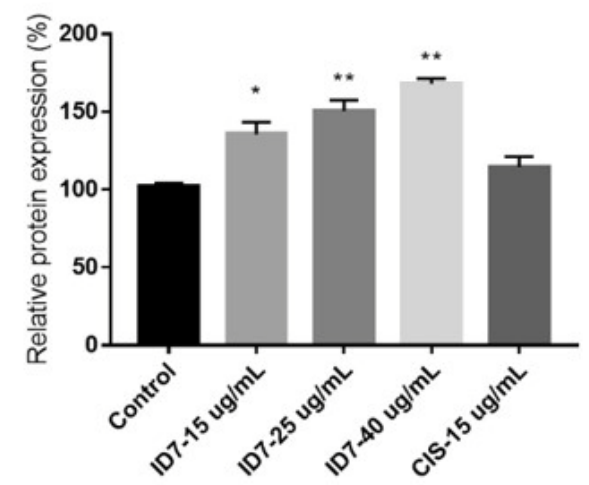

D

PARPc/PARP total

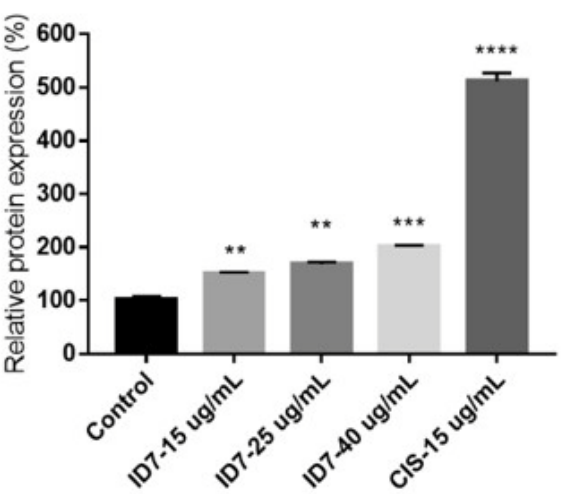

E

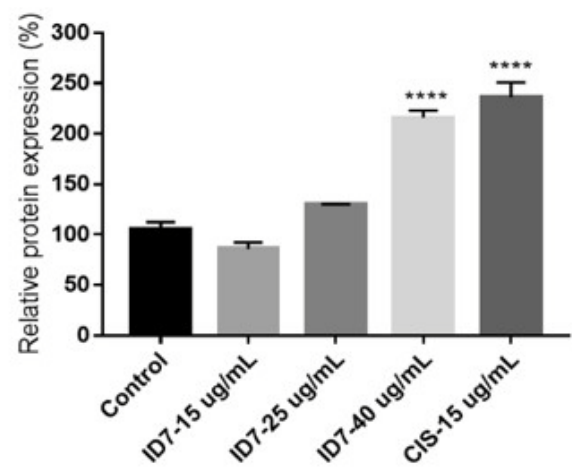

F

RIP

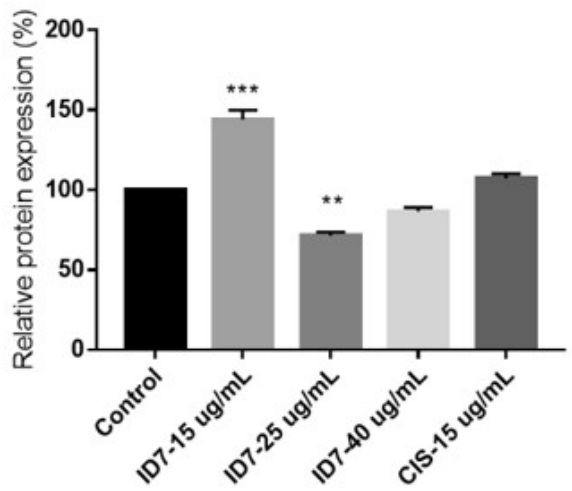

Fig. 4 Expression of cell death pathway proteins in ID7-treated $4 \mathrm{~T} 1$ cells $(15 \mu \mathrm{g} / \mathrm{mL}, 25 \mu \mathrm{g} / \mathrm{mL}$ and $40 \mu \mathrm{g} / \mathrm{mL}$ and Cisplatin $15 \mu \mathrm{g} / \mathrm{mL}$ ). A: protein expression of PARP/PARPc, Caspase 7/Caspase7-c, Caspase 8/Caspase 8-c, RIP, TNF-R1 and B-actin for normalization. B-F: densitometric analysis of western blotting data. B: Caspase 7-c/Caspase 7 “***» $p=0.0001 ; \mathrm{C}$ : TNF-R1 “*” $p=0.0109$, “**” $p=0.0005$; D: PARPc/PARP “**” $p=0.0078$, “***” $p=0.0003$, “****” $p<0.0001$; E: Caspase 8-c/Caspase8 “****” $p=0.0001 ;$ F: RIP “**” $p=0.0017$ “***” $p=0.0002$ (ANOVA One Way). 
A

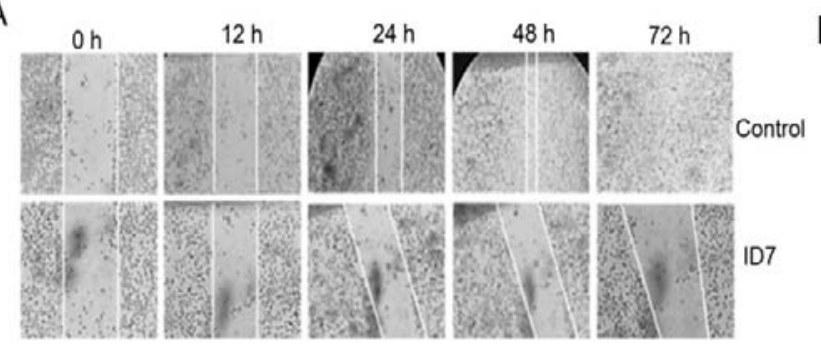

C
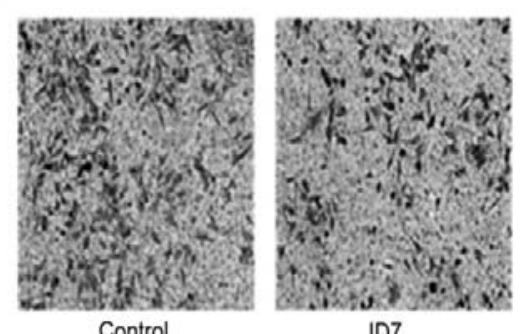

ID7

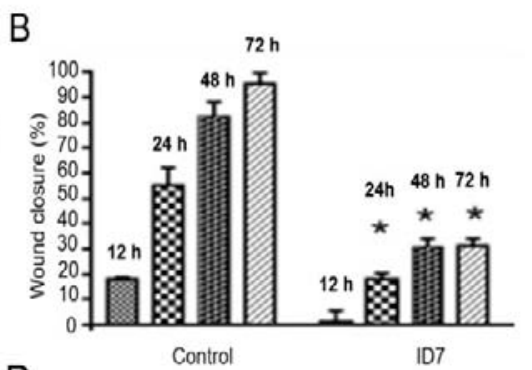

D

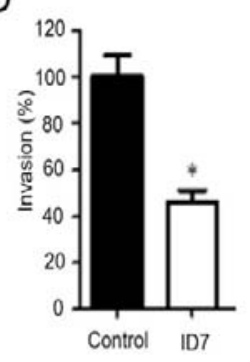

Fig. 5 ID7 Activity fraction on migration (wound healing) at 24, 48 and $72 \mathrm{~h}$ of treatment, and invasion (Boyden chamber) in $24 \mathrm{~h}$ of treatment of $4 \mathrm{~T} 1$ cells. Control: $1 \%$ DMSO. A: photomicrographs with $400 \times$ magnification of the wounds at 0 , 12, 24, 48 and $72 \mathrm{~h}$ after the start of treatment. B: wound closure percentage, $* p<0.05$ vs. vehicle control $(n=4) p=0.0001$ (ANOVA One Way). C: photomicrographs of the cells, treated with ID7 for $24 \mathrm{~h}$, able to invade through the basement membrane (Boyden chamber). D: invasion percentage, $* p<0.05$ vs. vehicle control $(n=4) p=0.0001$ (ANOVA One Way).

A

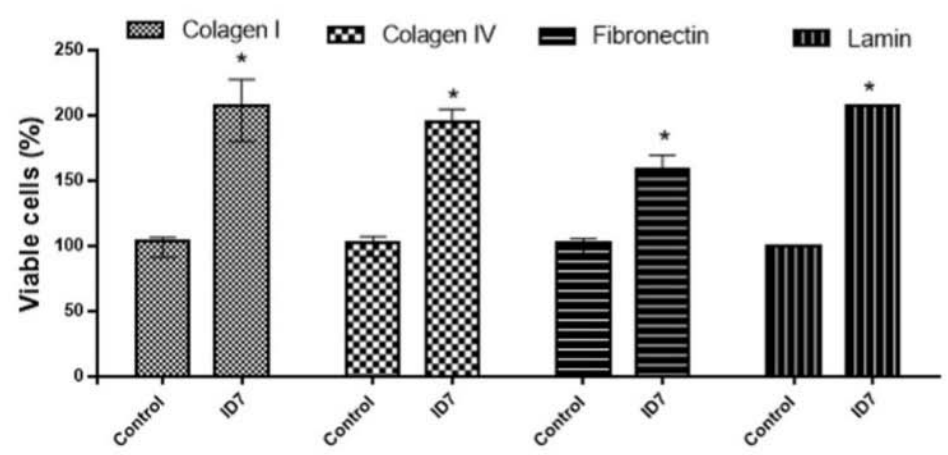

B

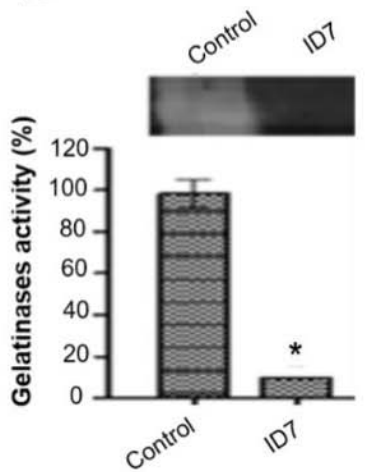

Fig. 6 A: Percentage of 4T1 cells adhered to components collagen I, collagen IV, fibronectin and laminin after treatment with ID7; B: Gelatine zymography assay revealed effects of ID7 on activity of gelatinases. Control: 1\% DMSO. Significant difference with $p=0.0001$ (ANOVA One Way). 
A

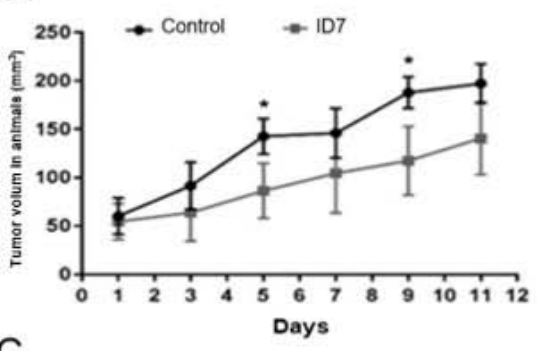

C

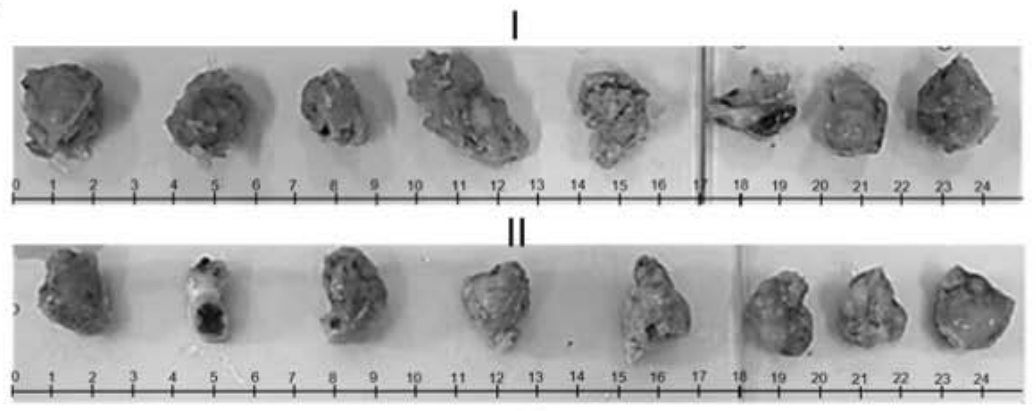

D

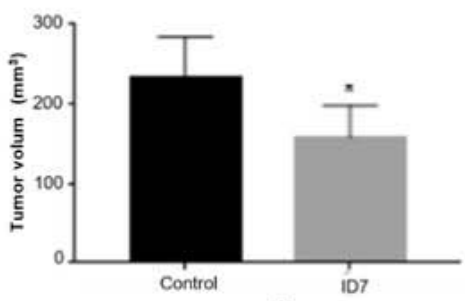

$\mathrm{F}$

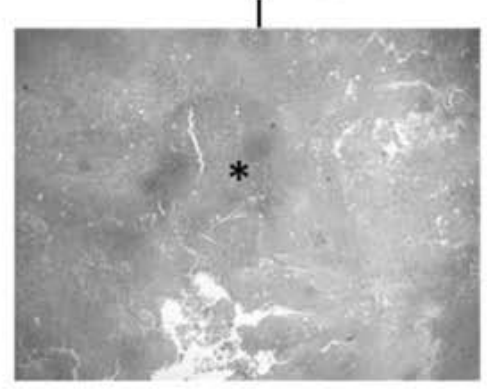

E
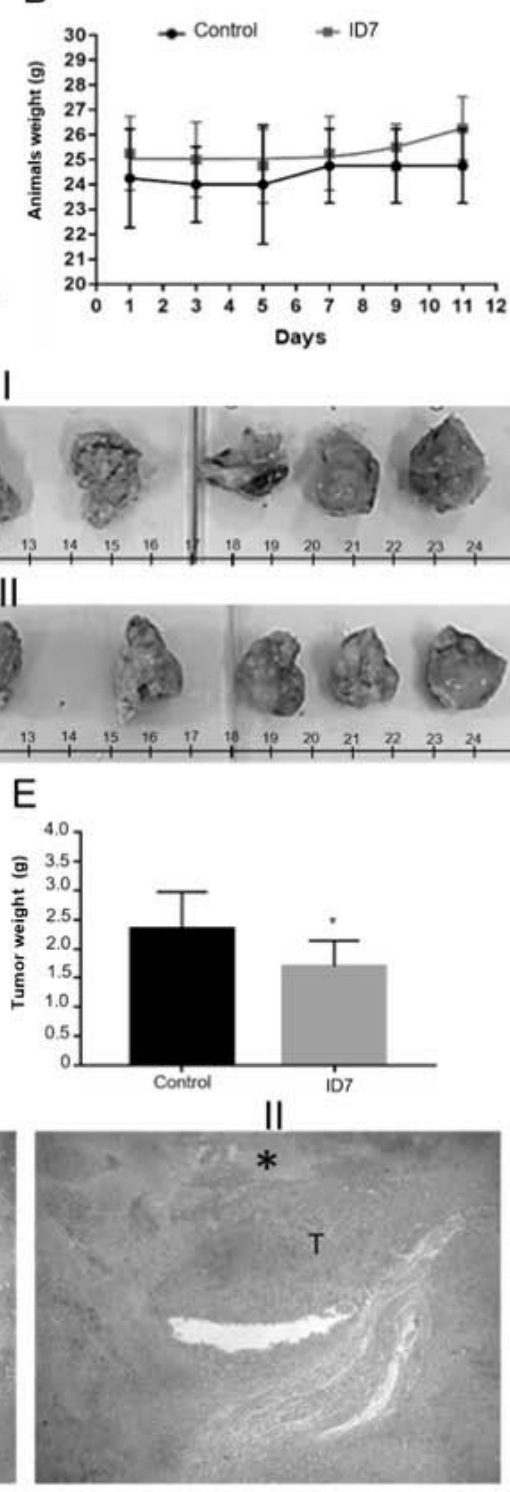

G

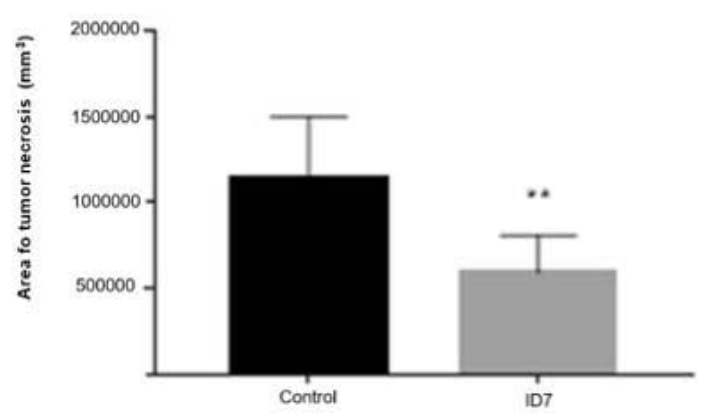

Fig. 7 ID7 activity on the development of $4 \mathrm{T1}$ tumor in mice. A: tumor volume in vivo ( $p=0.001)$; B: weight tumor in vivo (p= 0.001); C I: tumors removed after euthanasia of the animals of the control group ( $\mathrm{NaCl} 0.9 \%)$; C II: tumors removed after euthanasia of animals treated with ID7 $(30 \mathrm{mg} / \mathrm{kg})$. D: volume of tumors removed after euthanasia $(p=0.0204)$. E: weight of tumors removed after euthanasia $(p=\mathbf{0 . 0 3 5 4})$. Each column represents the mean of the tumor weight and volume of the animals in each group (ANOVA One Way). F: hematoxylin and eosin staining of tumor sections “*” area of necrosis. “T”: area of tumor mass. G: mean areas of tumor necrosis (“**” $p=0.0031$ ) (ANOVA One Way). 
A

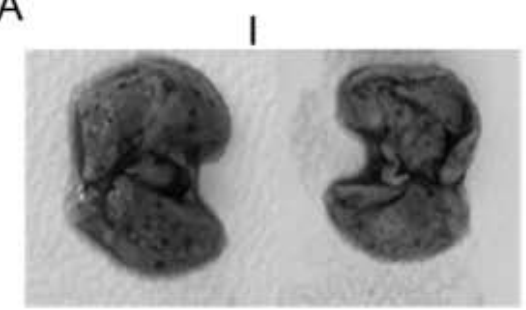

B

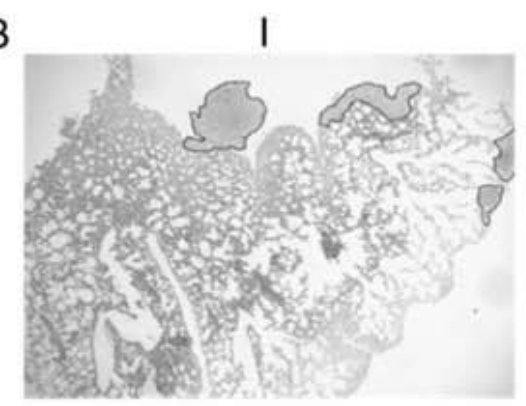

C

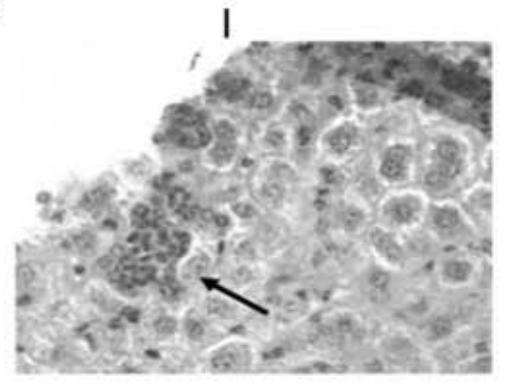

D

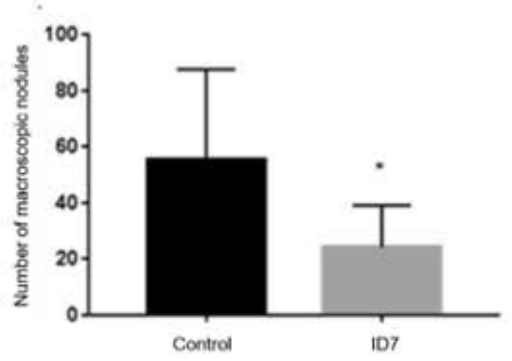

F

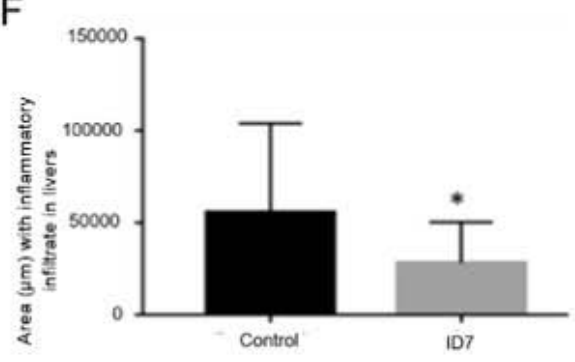

II

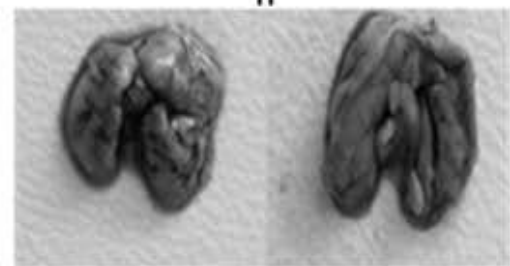

II

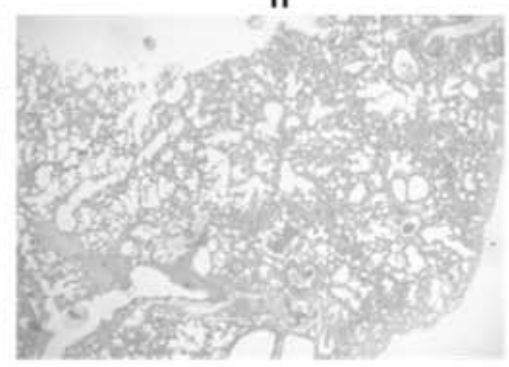

II

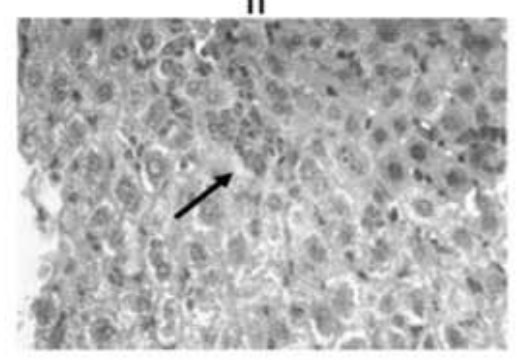

E

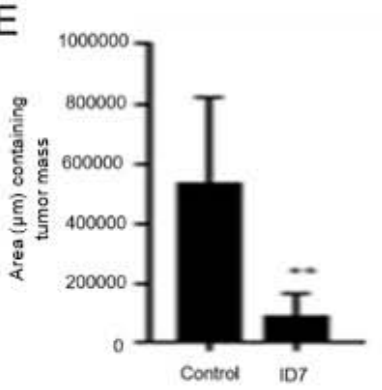

G

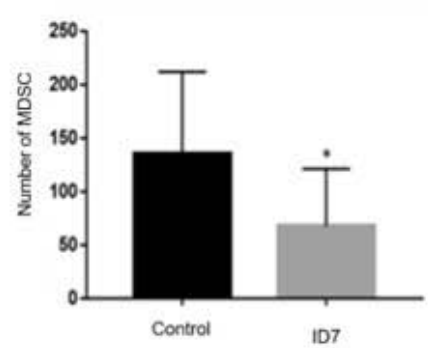

Fig. 8 ID7 activity on 4T1 metastasis. A I: lungs of control animals (0.9\% NaCl) with foci of metastasis (dark spots); A II: lungs of animals in the ID7-treated group ( $30 \mathrm{mg} / \mathrm{kg}$ ) with foci of metastasis (dark spots); B I: histological sections of the lungs (H/E) of the control group, foci containing tumor mass are circled in black; B II: histological sections of the lungs (H/E) of the ID7 group. C: histological sections containing possibly highlighted CMS (black arrow). D: metastasis number in the lungs of the control group and the group treated with ID7, $p=0.0239$. $\mathrm{E}$ : area $(\mu \mathrm{m})$ analysis containing defined tumor mass, $p=0.001$. F: analysis of the area $(\mu \mathrm{m})$ with inflammatory infiltrate in livers, $p=0.001$. G: analysis of the number of possibly MDSC in livers, $p=0.001$. Each column represents the mean between animals (ANOVA One Way). 
(Figs. 8C and 8F), as well as reduced the number of possible suppressor myeloid cells in the organ (Figs. $8 C$ and $8 G$ ).

\section{Discussion}

In this work, the antitumor and antimetastatic activities of the ID7 fraction, obtained from the stems of Bauhinia variegate L., were evaluated both in vitro and in vivo. Among the known substances found in this fraction were oleic acid, myricetin, quercetin and kaempferol. Among these, myricetin may exhibit an titumor activity on various types of cancer, such as papillary thyroid cancer (HPTC) [13] and is capable of considerably inhibiting the migration and invasion of cholangiocarcinoma [14]. In addition to this, quercetin may also be involved in the reported activities since this flavonoid has already been shown to suppress the mobility of breast cancer MCF-7 and MDA-MB-231 by negatively regulating the expression of cellular migration marker proteins, such as matrix metalloproteinase 2 (MMP-2), MMP-9 [15].

The characterization of ID7 also suggested the presence of kaempferol, which may likewise be related to the antitumor and antimetastatic activities found, since it is a phytoestrogen known to play a chemopreventive role [16]. In addition, a study showed that the presence of lipids in extracts containing phenolic compounds, as found in ID7, helps in the solubilization of these substances in the cells, which may potentiate their activity [17] explaining the relationship of these compounds with the results found. It is not clear yet, whether the observed activity might be due to a synergistic effect of the mixture of compounds in ID7-analogues to observed activity in fighting breast cancer with SM6Met from honey bush te [18].

ID7 fraction decreased the viability of $4 \mathrm{~T} 1$ by the assay using MTT, which estimates the activity of the mitochondrial dehydrogenases and by the trypan blue assay, which evaluates the integrity of the cytoplasmic membrane of these cells, providing an increase in the number of cells in late apoptosis. It is considered a potent antineoplastic activity natural substance with $\mathrm{IC}_{50} \leq 30 \mu \mathrm{g} / \mathrm{mL}$ [19].

The use of herbal medicines that cause less side effects but with antitumor potential has become increasingly popular [20]. Selectivity index (SI) is a way of assessing the ability to induce fewer side effects by determining how much a compound acts more on tumor cells than on normal cells. Consequently, the SI is fundamental for the screening of compounds for the future clinical tests [10]. Thus, in this work, the ID7 fraction showed to be a potential antitumor agent with less chance of causing side effects.

Two canonical pathways can trigger apoptosis: the intrinsic pathway, known as the mitochondrial pathway and the extrinsic pathway, which is dependent on cell surface receptors [21]. We believe that ID7 acts on the viability of 4T1 cells via apoptosis because the results showed characteristics of this event: the presence of loss of plasma membrane viability and decreased mitochondrial metabolism, as well as morphological alterations that characterize apoptosis, such as the formation of dense cytoplasm with fragmented nuclei and vacuoles in the cell membrane, as well as fragmented nuclei marked in red by IP [22].

In addition, the cleavages of PARP, TNF-R1, and FAS, which were increased in ID7 treatment are biochemical markers of apoptosis. Studies have proposed that the cell surface death receptor (FAS) pathway is enough to induce apoptosis through DISC assembly and succeeding caspase-8 activation, which in turn will activate the caspases executioner 3 or 7 [23]. Since caspases 7 and 8 also had their expression increased by ID7, we believe that this fraction induces the death of 4T1 cells by apoptosis via the extrinsic pathway [24]. Several tumor strains can develop routes to avoid apoptosis in order to survive [25]. Thus, the induction of apoptosis in tumor cells may be a promising treatment method in cancer therapy. In this context, products of natural origin have been increasingly used because of their ability to modulate 
this cell death pathway [26].

The 4T1 cell line is considered a triple negative breast cancer line [11] which is a highly aggressive type of breast cancer. The results showed that ID7 was selective for MDA-MB-231 cells that are also characterized as triple negative, since they do not have estrogen, progesterone or Her2 receptors [27]. Therefore, considering that the triple negative phenotype has a poor prognosis, with highly aggressive characteristics, and although the available cytotoxic or genotoxic drugs produce limited efficacy and significant adverse effects [28] the selective action evidenced in this work, ID7 on this tumor type is very relevant.

Cancer development includes pre-tumor injury, tumor formation and growth, and metastasis, which occur from a cascade of factors, including cell adhesion, migration, and extracellular matrix proteolysis [29]. As inhibition of metastatic potential is essential to improve the prognosis of breast cancer patients, this work sought to evaluate some of the mechanisms of metastasis. Thus, ID7 inhibited the migration of 4T1 cells, as well as the migration of the MDA-MB-231 cell line was inhibited with the treatment using Euphorbia humifusa extract [30]. Both ID7 and E. humifusa have Kaempferol as the secondary compound, that may be correlated with the activities described.

Another mechanism essential for the carcinoma metastasis is the invasion of the basement membrane [31]. For this, they produce proteases, such as gelatinases (MMP-2 and MMP-9), which degrade the extracellular matrix [31]. The invasion, cell migration and secretion of MMP-2 and MMP-9 from head and neck carcinomas were decreased by a mixture of phenolic compounds, in a dose-dependent manner [32]. Besides, previous studies have stated that inhibition of MMPs secretion or activity is correlated with inhibition of invasion and tumor progression [33, 34]. These data both suggest that ID7 acts as a potential agent against tumor metastasis, also by inhibiting the activity of gelatinases. In addition, in the tumor environment gelatinases have the role of degrading other components of the extracellular matrix (MEC), such as fibronectin, laminin, collagen I and collagen IV, responsible for adhesion of the cells to the ECM, thus facilitating the exit of the tumor environment. Therefore, we believe that the increase in adhesion of the ID7-treated 4T1 cells to the ECM components is related to the lower amount of gelatinases active in the supernatant of these cells.

In vivo results showed that the ID7 fraction inhibited tumor growth and inhibited metastasis to the lung and liver, reinforcing the previous findings of the action of ID7 on the mechanisms of metastasis. Tumor cells are commonly surrounded by various stromal cells including fibroblasts, angiogenic vascular cells and infiltrating immune cells [35]. Our histological analysis of the livers of the untreated animals showed a high number of defense cells, with a marked presence of the cells similar to myeloid-derived cells classified as a suppressor (MDSC). This class of cells contributes to and helps orchestrate tumor immunosuppression because they can interact with $\mathrm{T}$ cells, macrophages and NK cells to create a favorable environment for tumor progression [36]. In contrast, histological analysis of the livers of ID7 treated animals showed a reduction in the number of these cells.

As the therapies that control the primary tumor cancer site improve, the incidence of metastasis has increased and management of patients with metastasis remains a challenge [37]. Also, tumor-induced immunosuppression plays a crucial role in tumor evasion of the immune system [36]. Thus, it is believed that ID7 may play a role in the prevention of 4T1 metastasis, supporting in anti-tumor immunity.

The ID7 presented five compounds in its constitution. One of the viable ways for applying ID7 as an antitumor would be the isolation and recognition of the possible active principle. However, in the present study, distinct biological activities were observed by the treatment using ID7. Some plant extracts composed mainly of polyphenols have biological activities that 
are totally or partially lost when their constituents are tested separately. For example, the SM6Met extract obtained from $C$. subternata shows estrogenic activities due to ER $\alpha$ antagonism, ER $\beta$ agonism and antagonism of breast cancer cells proliferation. From the guided fractionation of SM6Met it was observed that it is unlikely that only one compound will be responsible for the estrogenic attributes, but rather that various compounds contribute to the activity of the extract either individually (additive) or inducing a synergistic effect [38]. The idea of intelligent mixtures in the investigation of activity, induced by a mixture of compounds, has become increasingly popular [18]. Thus, it is believed that the five compounds recognized in ID7 can act synergistically providing antitumor and antimetastatic activities found in this work.

\section{Conclusions}

The ID7 fraction showed a potential antitumor action, selectively acting on tumor development and metastatic mechanisms in vitro. Also it showed decrease of 4T1 tumor growth, lung metastasis and inflammation in the livers of mice. Finally, we conclude that fatty acids and kaempferol might be related to these activities.

\section{Acknowledgments}

The authors sincerely appreciate Dr. Evelyn Wolfram and Dr. Samuel Peter for helping us with the HPLC analysis of the compounds and reviewing the text.

\section{Funding}

This study was supported by FAPEMIG (PPM-00229-16). This work was conducted during a scholarship supported by the International Cooperation Program CAPES (Brazilian Federal Agency for Support and Evaluation of Graduate Education within the Ministry of Education of Brazil)/PMBqBM at the Federal University of São João del Rei.

\section{Ethics Approval}

All animal tests were approved by Animal Research Ethics Committee of the Federal University of São João del Rei under code 027/2016-A, adhering to ethical guidelines of the Basel Declaration and the International Council for Laboratory Animal Science (ICLAS).

\section{Conflict of Interest}

The authors of this paper declare that they do not have conflicts of interest to be revealed. This work was funded by the Ministry of Science, Technology, Innovations and Communications (CNPQ), Coordination of Improvement of Higher Level Personnel and Foundation of Support to the research of Minas Gerais (FAPEMIG).

\section{References}

[1] Rangarao, R., Smruti, B. K., Singh, K., Gupta, A., Batra, S., Choudhary, R. K., Sahani, S., Kabra, V., Parikh, P. M., and Aggarwal, S. 2018. "Practical Consensus Recommendations on Management of Triple-Negative Metastatic Breast Cancer.” South Asian J Cancer 7 (2): 27-131.

[2] Golubnitschaja, O., Yeghiazaryan, K., Abraham, J., Schild, H. H., Costigliola, V., and Debald, M. 2016. "Breast Cancer Risk Assessment: A Non-invasive Multiparametric Approach to Stratify Patients by MMP-9 Serum Activity and RhoA Expression Patterns in Circulating Leucocytes.” Amino Acids 49 (2): 273-81.

[3] Lou, C., Zhu, Z., Zhao, Y., Zhu, R., and Zhao, H. 2016. "Arctigenin, a Lignan from Arctiumlappa L., Inhibits Metastasis of Human Breast Cancer Cells through the Downregulation of MMP-2/-9 and Heparanase in MDA-MB-231 Cells.” Oncol Rep. 37 (1): 179-84.

[4] Gialeli, Ch., Viola, M., Barbouri, D., Kletsas, D., Passi, A., and Karamanos, N. K. 2014. "Dynamic Interplay between Breast Cancer Cells and Normal Endotheliummediates the Expression of Matrix Macromolecules, Proteasome Activityand Functional Properties of Endothelial Cells.” Biochimica et Biophysica Acta. 1840 (8): 2549-59.

[5] Cheng, Y. T., Yang, C. C., and Shyura, L. F. 2016. "Phytomedicine-Modulating Oxidative Stress and the Tumor Microenvironment for Cancer Therapy." Pharmacological Research 114: 128-43. 
[6] Chew, Y. L., Lim, Y. Y., Stanslas, J., Ee, G. C., and Goh, J. K. 2014. "Bioactivity-Guided Isolation of Anticancer Agents from Bauhinia Kockiana Korth.” Afr. J. Tradit Complement Altern Med. 11 (3): 291-9.

[7] Kaewpiboon, C., Lirdprapamongkol, K., Srisomsap, C., Winayanuwattikun, P., Yongvanich, T., Puwaprisirisan, P., Svasti, J., and Assavalapsakul, W. 2012. "Studies of the in Vitro Cytotoxic, Antioxidant, Lipase Inhibitory and Antimicrobial Activities of Selected Thai Medicinal Plants.” BMC Complementary and Alternative Medicine 12 (217).

[8] Santos, K. M., Gomes, I. N. F., Silva-Oliveira, R. J., Pinto, F. E., Oliveira, B. G., Chagas, R. C. R., Romão, W., Reis, R. M. V., and Ribeiro, R. I. M. A. 2018. "Bauhinia variegata candida Fraction Induces Tumor Cell Death by Activation of Caspase-3, RIP, and TNF-R1, and Inhibits Cell Migration and Invasion in Vitro.” Biomed Research 5: $1-10$.

[9] Lima, D. A., Müller, C., Costa, A. C., Batista, P. F., Dalvi, V. C., and Domingos, M. 2017. "Morphoanatomical and Physiological Changes in Bauhinia variegata L. as Indicators of Herbicide Diuron Action.” Ecotoxicology and Environmental Safety 141: 242-50.

[10] Suffness, M., and Pezzuto, J. M. 1991. "In Assay Related to Cancer Drug Discovery." In Methods in Plant Biochemistry Assays for Bioactivity, edited by Hostettmann, K., 6.

[11] Silva, V. L., Ferreira, D., Nobrega, F. L., Martins, I. M., Kluskens, L. D., and Rodrigues, L. R. 2016. "Selection of Novel Peptides Homing the 4T1 CELL Line: Exploring Alternative Targets for Triple Negative Breast Cancer.” PLOS ONE 11 (8).

[12] Thirugnanasampandan, R., Ramya, G., and Gogulramnath, M. 2016. "Antigenotoxic and Apoptotic Activities of Essential Oil of Atalantiamonophylla Correa." Indian $J$ Pharmacol 48 (6).

[13] Ha, T. K., Jung, I., Kim, M. E., Bae, S. K., and Lee, J. S. 2017. "Anti-cancer Activity of Myricetin against Human Papillary Thyroid Cancer Cells Involves Mitochondrial Dysfunction-Mediated Apoptosis.” Biomed Pharmacother 91: 378-84.

[14] Tuponchai, P., Kukongviriyapan, V., Prawan, A., Kongpetch, S., and Senggunprai, L. 2019. J Cancer Res Ther. 15 (1): 157-63.

[15] Jia, L., Huang, S., Yin, X., Zan, Y., Guo, Y., and Han, L. 2018. "Quercetin Suppresses the Mobility of Breast Cancer by Suppressing Glycolysis through Akt-mTOR Pathway Mediated Autophagy Induction.” Life Sci. 1 (208): 123-30.

[16] Hao, D. C., Ge, G. B., and Xiao, P. G. 2016. "Nticancer Drug Targets of Salvia phytometabolites: Chemistry, Biology, and Omics.” Curr Drug Targets.
[17] Alu'datt, M. H., Rababah, T., Ereifej, K., Gammoh, S., Alhamad, M. N., Mhaidat, N., et al. 2014. "Investigation of Natural Lipid-Phenolic Interactions on Biological Properties of Virgin Olive Oil.” J Agric Food Chem. 10 (62): 11967-75.

[18] Mortimer, M., Visser, K., Beer, D., Joubert, E., and Louw, A. 2015. "Divide and Conquer May Not Be the Optimal Approach to Retain the Desirable Estrogenic Attributes of the Cyclopia Nutraceutical Extract, SM6Met.” PLoS ONE 10 (7): e0132950.

[19] Itharat, A., Houghton, P. J., Eno-Amooquaye, E., Burke, P. J., Sampson, J. H., and Raman, A. 2004. "In Vitro Cytotoxic Activity of Thai Medicinal Plants Used Traditionally to Treat Cancer." Journal of Ethnopharmacology 90 (1): 33-8.

[20] Kannan, N., Sakthivel, K. M., and Guruvayoorappan, C. 2016. "Anti-tumor and Chemoprotective Effect of Bauhinia tomentosaby Regulating Growth Factors and Inflammatory Mediators.” Asian Pac J Cancer Prev. 16 (18): 8119-26.

[21] Mcilwain, D. R., Berger, T., and Mak, T. W. 2013. "Caspase Functions in Cell Death and Disease." Cold Spring Harb Perspect Biol. 5 (4): a008656.

[22] Delphi, L., Sepehri, H., Khorramizadeh, M. R., and Mansoori, F. 2016. "Pectic-Oligoshaccharides from Apples Induce Apoptosis and Cell Cycle Arrest in MDA-MB-231 Cells: A Model of Human Breast Cancer.” Asian Pacific Journal of Cancer Prevention 16 (13): 5265-71.

[23] Krammer, P. H., Arnold, R., and Lavrik, I. N. 2007. "Life and Death in Peripheral T Cells.” Nat. Rev. Immunol 7 (7): 532-42.

[24] Mishra, A., Sharma, A. K., Kumar, S., Saxena, A. K., and Pandey, A. K. 2013. "Bauhinia variegata Leaf Extracts Exhibit Considerable Antibacterial, Antioxidant, and Anticancer Activities.” Biological Medical Research International 11.

[25] Hanahan, D., and Weinberg, R. 2011. "Hallmarks of Cancer: The Next Generation.” Cell 144 (5): 646-74.

[26] Fulda, S. 2010. "Modulation of Apoptosis by Natural Products for Cancer Therapy.” Planta Med. 76 (11).

[27] Kaur, P., Nagaraja, G. M., Zheng, H., Gizachew, D., Galukande, M., Krishnan, S., and Asea, A. 2010. “A Mouse Model for Triple-Negative Breast Cancer Tumor-Initiating Cells (TNBC-TICs) Exhibits Similar Aggressive Phenotype to the Human Disease.” BMC Cancer 12 (1): 120.

[28] Kim, D., Radin, D., and Leonardi, D. 2017. "Probing the Molecular Mechanisms Governing the Oncolytic Activity of Paeonia suffruticosaon Triple-Negative Breast Cancer Cells in Vitro.” Anticancer Research 37 (9): 4813-9.

[29] Steeg, P. S. 2003. "Metastasis Suppressors Alter the 
Signal Transduction of Cancer Cells.” Nature Rev Cancer 3.

[30] Deng, F., Tang, N., Xu, J., Shi, H., Zhao, M., and Zhang, J. 2008. "New a-Pyrrolidinonoids and Glycosides from Euphorbia humifusa.” Journal of Asian Natural Products Research 10 (6).

[31] Deryugina, E. I., and Quigley, J. P. 2015. “Tumor Angiogenesis: MMP-Mediated Induction of Intravasationand Metastasis-Sustaining Neovasculature.” Matrix Biol. 44-46: 94-112.

[32] Folgueras, A. R., Pendas, A. M., Sanchez, L. M., and Lopez-Otin, C. 2004. "Matrix Metalloproteinases in Cancer: From New Functions to Improved Inhibition Strategies.” International Journal of Developmental Biology 48: 411-24.

[33] Niedzwiecki, A., Roomi, M. W., Kalinovsky, T., and Rath, M. 2016. “Anticancer Efficacy of Polyphenols and Their Combinations.” Nutrients 8 (9): 552.

[34] Jia, W., Gao, X. J., Zhang, Z. D., Yang, Z. X., and Zhang,
G. 2013. "S100A4 Silencing Suppresses Proliferation, Angiogenesis and Invasion of Thyroid Cancer Cells through Downregulation of MMP-9 and VEGF.” Eur Rev Med Pharmacol Sci. 17 (11): 1495-508.

[35] Shuman-Moss, L. A., Jensen-Taubman, S., and Stetler-Stevenson, W. G. 2012. "Matrix Metalloproteinases: Changing Roles in Tumor Progression and Metastasis.” Am. J. Pathol. 181 (6): 1895-9.

[36] Hanahan, D., and Coussens, L. M. 2012. “Accessories to the Crime: Functions of Cells Recruited to the Tumor Microenvironment.” Cancer Cell 21.

[37] Ilkovitch, D., and Lopez, D. M. 2009. “The Liver Is a Site for Tumor Induced Myeloid-Derived Suppressor Cel Accumulation and Immunosuppression." Cancer Res. 69 (13): 5514.

[38] Gertsch, J. 2011. "Botanical Drugs, Synergy, and Network Pharmacology: Forth and Back to Intelligent Mixtures.” Planta Medica. 77: 1086. 